\title{
JOSÉ DE ANCHIETA, O TEATRO E A EDUCAÇÃO DOS MOÇOS DO COLÉGIO DE JESUS NA BAHIA DO SÉCULO XVI
}

\author{
Paulo Romualdo Hernandes \\ Universidade Federal de Alfenas - UNIFAL - MG \\ paulorh_mancini@hotmail.com
}

\section{RESUMO}

Este estudo trata do teatro educativo jesuítico no Brasil do século XVI. Aborda o teatro de Anchieta e tem como objeto específico de pesquisa a peça "Diálogo de Pero Dias", que teria sido apresentada no Colégio de Jesus na ciudad do Salvador, na Bahia. Um auto na fórmula de diálogo, por meio de perguntas e respostas, como o catecismo tridentino, preparadas para a catequese. Diálogo que teria como espectadores, provavelmente, os colonos, viajantes, homens do governo, soldados, mas como alvo principal de seus ensinamentos os "moços" do colégio. O objetivo deste estudo é fazer uma nova leitura dessa peça de Anchieta para resgatar, a partir de uma leitura crítica baseada em Foucault, os ensinamentos que os padres jesuítas pretendiam para os "moços", mas também para outras personagens sociais do Brasil do século XVI.

Palavras-chave: teatro jesuítico; Brasil quinhentista; José de Anchieta; pedagogia-brasílica.

\section{JOSÉ DE ANCHIETA, THE THEATRE AND EDUCATION OF THE YOUNG MEN OF COLLEGE OF JESUS IN BAHIA OF THE SIXTEENTH CENTURY}

\begin{abstract}
This study deals with the Jesuit educational theater in the $16^{\text {th }}$ century in Brazil. Addresses on the theater of Anchieta and has as its specific aim of study the play "Pero Dias Dialogue", which should have been presented in the Society of Jesus in Bahia.

A dialogue based on questions and answers prepared for catechesis which would have as spectators, probably, settlers, travelers, men of government, soldiers, but as the main target of his teachings, the "young men" of the College. The purpose of this paper was to re-read this play of Anchieta to recover from a critical appraisal based on Foucault, the teachings which the Jesuit priests sought to "young men", but also to other historical figures of Brazil in the $16^{\text {th }}$ century.
\end{abstract}

Keywords: Jesuit theater; sixteenth-century Brazil; José de Anchieta; Brasilic-pedagogy.

\section{Introdução}

Neste artigo apresenta-se um estudo sobre o teatro pedagógico, de moralidades, no Brasil do século XVI, que teve lugar, mais provavelmente, no Colégio de Jesus, na ciudad de Salvador. É, portanto, um resgate de um acontecimento "único" do Brasil quinhentista, nesta leitura que se faz tendo como método de análise o pensamento de Michel Foucault. Busca-se neste estudo, na voz do Mesmo, do padre jesuíta José de Anchieta, em seu teatro e nas suas cartas, e de outros padres missivistas, também nos sussurros do Outro, os moços do Colégio ou os colonos, entender o processo histórico da educação, do teatro, no século XVI, sob nova óptica, com novos documentos, nova metodologia, e, então, estender a história da educação desse período para além daquela de nossos "pais” (Febvre, 1970). 
Apesar de ter como elemento singular de pesquisa a peça "Diálogo de Pero Dias", este trabalho não se inscreve na dita micro-história, "modo de fazer pesquisa fragmentada, sem uma visão de totalidade" (Bittar; Ferreira, 2009, p. 500), ou seja, de interpretar a peça em si sem vínculo com a realidade social em que ela foi realizada (Bittar; Ferreira, 2007), mas de fazer um resgate de um acontecimento "raro" do Brasil do princípio de sua colonização, tendo como método de análise da peça, mas também de cartas, de documentos, o pensamento de Michel Foucault: ler a prática discursiva em um evento singular relatada no teatro, nas cartas dos padres jesuítas e outros cronistas da época para tentar encontrar os fios da trama dos discursos de religiosidade e moralidade, ainda que com uma leitura e interpretação feita no século XXI.

Nos nossos dias, parece ter saído de moda o estudo desse período para privilegiar a pesquisa das coisas do cotidiano, atuais e que mereceriam mais atenção. No entanto, esse resgate é importante para compreendermos a fundação não só da religiosidade brasileira, mas também da educação e do nascimento do teatro, pois muitas "verdades" desse período estão cristalizadas (por exemplo, que o teatro de Anchieta não é teatro, mas teatrinho catecismo) e precisam ser examinadas novamente (Bittar, 2006, p. 8). Segundo Bittar e Ferreira (2007, p. 109), aliás, há toda uma "matriz de uma determinada visão da história da educação brasileira" que merece ser revista.

O teatro de José de Anchieta é uma "raridade" para o estudo da história da educação (cf. Veyne, 2008) porque é um acontecimento no Brasil do início de sua formação. Embora seja um teatro com forma estética europeia, pois foi elaborado por alguém que nasceu nas Ilhas Canárias e que estudou em Coimbra, é pedagógico, ou seja, sua função é educativa, nem tanto artística. Portanto, seus tipos, suas personagens, seus espectadores e, sobretudo, o conteúdo de seus ensinamentos pertencem a um universo bem diferente dos autos pedagógicos europeus, sobretudo de Gil Vicente, a quem o teatro de Anchieta tem sido constantemente comparado. Segundo José Augusto Bernardes (2000), um dos principais estudiosos do teatro vicentino atualmente, Anchieta teria se inspirado em alguns modelos do teatro Medieval, em que também Mestre Gil teria se inspirado, mas não necessariamente em Gil Vicente. Há, segundo Bernardes (idem, p. 751), "diferenças essenciais, uma vez que são exatamente essas diferenças que libertam Anchieta da condição de mais um seguidor tardio e aculturado de uma fantasiosa e indelimitada 'escola vicentina". No teatro de Anchieta, há uma síntese de ideias reveladoras desse período; aquela da religiosidade, da moral, da estética artístico-teatral, da pedagogia europeias, trazidas por Anchieta, pelos colonizadores, ideias essas que aqui entraram em confronto com a realidade do Brasil quinhentista: uma cidade e um Colégio encravados em meio à mata selvagem.

Anchieta compôs muitas peças de teatro: algumas para nativos, mamelucos e colonos, mais ou menos importantes econômica e politicamente; algumas para a catequese dos meninos, mais especificamente os órfãos que vinham de Portugal, os filhos dos colonos, os órfãos da terra que muito os há por aqui (Nóbrega, 1988, p. 74) e alguns meninos índios ou faltos da doutrina. Fez autos para uma plateia que teria maior conhecimento "das coisas da fé", estudantes dos Colégios, colonos principais da terra, padres. É o caso do "Diálogo de Pero Dias", cujo estudo será apresentado neste artigo. É possível que esta peça tenha acontecido no Colégio de Jesus, na Bahia, que era o mais importante colégio jesuíta do Brasil. Nessa época, Salvador era a principal cidade do Brasil, já que era sede de residência do Bispo e do Governador.

Essa peça tem como objetivo pedagógico ensinar aos moços do colégio o que devem fazer, espelhando-se em Pero Dias, mártir jesuíta e personagem da peça, para viver suas vidas, mas, sobretudo, salvar a alma. Na peça, Cristo é a personagem que dialoga com 
Pero Dias, ambos agindo como se fossem padre jesuíta e estudante do Colégio em um diálogo aos moldes do Catecismo Tridentino, diálogo sobre a doutrina na forma de perguntas e respostas, que faz com que essa peça se inscreva no maravilhoso teatro jesuítico, embora realizada longe das cidades europeias e em meio à mata selvagem do Brasil do século XVI.

\section{Os estudantes do Colégio de Jesus e o teatro}

A realização de teatro no Brasil é anterior às representações jesuíticas. Aliás, a primeira peça jesuíta de que se tem notícia, o auto da Pregação Universal, foi composta e realizada, a pedido de Nóbrega, pelo então irmão José de Anchieta, para substituir um auto que os moradores de Piratininga ou São Vicente queriam fazer para "véspera da Circuncisão" (Anchieta, 1977, p. 51), provavelmente entre os anos de 1561 e 1567, segundo Leite (2004, p. 409). Nos fragmentos históricos, Anchieta conta como foi essa primeira apresentação de teatro jesuíta. Escreve Anchieta que Nóbrega "era tão zeloso de se pregar a palavra de Deus" que até mesmo os irmãos que não eram ainda sacerdotes, mas que eram bom pregadores, fazia pregar "na língua português e brasil". Por isso e para "impedir alguns abusos que se faziam em autos nas igrejas, fez um ano com os principais da terra que deixassem de representar um que tinham, e mandou-lhes fazer outro por um irmão (grifo nosso), a que ele chamava de Pregação Universal" (1988, p. 482). Foi chamado assim porque se representava em vários lugares da costa e fazia grande sucesso, reunindo índios e portugueses, por ser falado em tupi e português. O irmão ${ }^{1}$ era Anchieta, segundo um de seus primeiros biógrafos, Pero Rodrigues (Caxa; Rodrigues, 1988, p. 79) que havia convivido com o jesuíta canarino no Brasil do século XVI.

Os jesuítas notariam, desde o início da sua missão no Brasil, que nas suas festas religiosas, momentos em que reuniam a cristandade, ou os índios, ou o povo de forma geral, era fundamental utilizar dança, música e representação para atrair o povo, o que despertava muita devoção nos fieis, trazia-os para a confissão, comunhão e possibilitava a salvação de suas almas. Manuel da Nóbrega, ainda em 1552, pedindo esclarecimentos para o provincial de Portugal, padre Simão Rodrigues, pergunta: "se nós abraçarmos com alguns costumes deste gentio como cantar cantigas de Nosso Senhor em sua língua pelo tom e tanger seus instrumentos de música que eles usam em suas festas quando matam contrários e quando andam bêbados [...]" (Leite, 1954a, p. 407). O esclarecimento era porque essas práticas contrariavam as Constituições da Companhia. Inácio de Azevedo (Leite, 1960, p. 485), primeiro visitador da Companhia de Jesus no Brasil, em carta de 1568, relatando sua visita, escreve: "Acerca de cantar missa e outros ofícios divinos e processiões onde há curas e vigários, que o fazem em sua Igreja, os nossos guardem as Constituições", pois se devia procurar ajudar as almas com confissões, comunhões e ensinando a doutrina evitando-se, assim, "a emulação dos curas". Loyola proibiu a inclusão de coro, música, dança, mesmo recitação, ou qualquer outra forma de ofício que não os sacramentos divinos nos trabalhos da Companhia, pois que isto desviaria os companheiros de Jesus de sua missão, que era salvar almas por meio da Conversão, do Batismo, da Confissão, da Comunhão. Que deixassem esses ofícios (música, canto, dança) para outras Igrejas, que já o faziam muito bem. Nos colégios era permitido apenas "recitar nas vésperas e nos domingos ou dias santos, mas evitando a polifonia ou cantochão" (Constituições, 1997, p. 185).

Não obstante um dos votos dos jesuítas ser a obediência, aliás, obediência de cadáver, esse voto não parece ter sido respeitado em relação a música, dança e representações nos trabalhos da Companhia na Europa e tampouco no Brasil. Na Baviera, 
tem-se notícia de que, em 1597, houve uma festa religiosa com muitos aparatos cênicos, de música, dança e representações. Naquele ano, os jesuítas apresentaram, na Baviera, "um teatro maravilhoso em que anjos e santos se digladiavam pelos céus de Munique, impulsionados pelas maquinarias da engenharia teatral, produzida por experientes artífices, mestres marceneiros" (Hernandes, 2006, p. 19).

No Brasil, também, essa desobediência às Constituições teria sido praticada, pois nas cartas de Antonio Blasques ou nos relatos de Fernão Cardim apresentam-se muitas descrições de festas religiosas, com muitas músicas, danças, inclusive com a participação de meninos índios nus, assim como mulheres índias dando louvas ao Senhor. Até Cristóvão Gouveia, o visitador jesuíta de 1583, que presenciou inúmeras festas no Brasil, relatadas pelo padre Cardim, seu acompanhante, recomendou que se fizessem as representações na língua portuguesa e não em latim, para que todos as entendessem (Leite, 2004, p. 407).

Mas essa desobediência foi sempre motivo de crítica e reprovação por parte dos homens da Companhia de Roma. O padre Marçal Beliarte, provincial, em seu Memorial de 1594, explicando a necessidade das representações, expõe assim o assunto para o Geral da Companhia, Cláudio Aquaviva:

porque, por outra parte, parece que são necessárias, assim para achar mordomos (pessoas de fora da Companhia), que lhe deem lustre como para ajudar o pouco que a terra ajuda às coisas de devoção, porque nelas há grande número de gente e, com isso, garante grande número de confissões e comunhões e nós não pomos de nossa casa mais que fazer a obra e ensaiá-la, que o gasto o fazem os mordomos, item, se deve permitir pelas mesmas causas fazer-se na Igreja algumas obrazinhas devotas, como já se fizeram e com proveito espiritual do próximo (ibidem).

A resposta de Roma é que o Provincial deveria cuidar para que não se gastasse muito nisso, ainda que fossem os de fora; deveria ver o que se representava para ser obra pia e boa e que não se representasse nas igrejas. Mais tarde, o Padre Geral, Cláudio Aquaviva, chama a atenção do Provincial do Brasil, pois que tinham representado comédias e tragédias sem o consentimento dele, e proíbe a presença de mulheres nas representações. Mais tarde ainda, em 1598, volta a chamar a atenção do padre Beliarte, para que se cumpra a Constituição, posto que continuam as representações. $O$ padre visitador, Manuel de Lima, em 1610, insiste que se cumpram as leis da Companhia. Segundo Leite (2004, p. 408), os jesuítas do Brasil deixavam de informar o que faziam aqui porque sabiam da realidade brasileira e das necessidades que tinham, por exemplo, de incluir nas suas festas religiosas, seja para colonos, estudantes ou índios, as representações, para que Roma não as proibisse. A conclusão de Leite, um jesuíta do século XX: "a influência do meio era superior a todas as determinações legais" (Leite, 2004, p. 409).

Por aqui, essa influência do meio, que provocava uma desobediência legal, foi nomeada de pedagogia brasílica e atribuída ao trabalho do padre Nóbrega em privilegiar no trabalho evangelizador a superação das dificuldades da realidade brasileira em detrimento de algumas regras da Companhia. Seria, certamente, a mesma pedagogia de Anchieta. Segundo Ferreira e Bittar (2004), a educação promovida no Brasil antes da promulgação da Ratio Studiorum foi uma “invenção' de Anchieta e seus companheiros" e teve como particularidade ser uma "experiência nascida do ambiente e das condições históricas dadas do que de uma fidelidade absoluta aos preceitos emanados da ContraReforma", levando-se em conta o "isolamento quase total em que viveram os jesuítas do primeiro século no Brasil” (p. 173). 
Anchieta teria composto ${ }^{2}$ várias peças de teatro para muitos gostos e públicos. Peças para os colonos mais "rudes", para os índios, para os homens do governo, para visitantes em missão no Brasil, para colonos principais da terra e para estudantes. Os autos mais elaborados, como "Diálogo de Pero Dias", que apresentavam maior necessidade de conhecimentos da doutrina, eram comumente preparados pelos professores de Humanidades e representados pelos estudantes dos colégios. Há uma relação e descrição de peças (Leite, 2004, p. 419) realizadas pelos estudantes nas comemorações de suas confrarias, Confraria de Nossa Senhora dos Estudantes, que, segundo Beliarte, teria realizado uma obrazinha devota, quando iniciavam os cursos nos Colégios, como Écloga Pastoril, outras quando terminavam os cursos, como Tragédia do Rico Avarento e de Lázaro pobre", entre outras, confrarias, datas, festas e peças.

Cardim faz uma descrição de uma representação feita pelos estudantes em Salvador, que muito interessa para este estudo, pois aconteceu no Colégio de Jesus, em 1584, tempo (aproximado) e lugar em que se supõe tenha sido realizada a peça "Diálogo de Pero Dias":

Ao dia seguinte, por ser dia das Onze Mil Virgens, houve no colégio grande festa da confraria das Onze Mil Virgens, que os estudantes têm a seu cargo, disse missa cantada um padre diácono e subdiácono. Os padrinhos foram o padre Luís da Fonseca, reitor, e eu com nossas capas de asperges. A missa foi oficiada com boa capela dos Índios, com flautas e de alguns cantores da Sé, com órgãos, cravos e descantes. E, ela acabada, se ordenou a procissão dos estudantes, aonde levamos debaixo do pálio três cabeças das Onze Mil Virgens, e as varas levaram os vereadores da cidade, e os sobrinhos do Sr. governador. Saiu na procissão uma nau à vela por terra, mui formosa, toda embandeirada, cheia de estudantes, e dentro nela iam as Onze Mil Virgens ricamente vestidas, celebrando seu triunfo. De algumas janelas falaram à cidade, collégio, uns anjos todos mui ricamente vestidos. Da nau se dispararam alguns tiros de arcabuzes, e o dia de antes houve muitas invenções de fogo, na procissão houve danças, e outras invenções devotas e curiosas. À tarde se celebrou o martírio dentro na mesma nau, desceu uma nuvem dos Céus, e os mesmos anjos lhe fizeram um devoto enterramento; obra foi devota e alegre, concorreu toda a cidade por haver jubileu e pregação (Cardim, 1980, p. 165).

Percebe-se nessa descrição que as obras devotas eram bem elaboradas, com índios tocando flautas, danças de estudantes, de meninos índios e outras invenções curiosas, bem como adereços cênicos. Não parece se tratar de uma "obrazinha devota", mas de teatro que teria forte influência, como diz Bernardes (2000), de modelos do teatro medieval; as alegorias, "cidade" e "colégio", a quem os anjos falaram das janelas das casas; a celebração do martírio dentro mesmo da Nau, que, segundo Leite, tinha "oito rodas de madeira escondidas" (2004, p. 409, em nota). Tem também algo do maravilhoso teatro jesuítico, tal qual o da Baviera, nessa descrição: a celebração do martírio dentro da nau, em que desceu uma nuvem dos Céus, e os anjos fazendo um devoto enterramento.

Em 1583, quando o padre visitador chegou ao Brasil e foi recebido no Colégio de Jesus, Cardim descreve a recepção que os estudantes fizeram ao receberem para sua confraria uma cabeça das Onze Mil Virgens trazida como relíquia pelo padre Cristóvão Gouveia, que aqui se juntariam às duas já existentes: 
Trouxe o padre uma cabeça das Onze Mil Virgens, com outras relíquias engastadas em um meio corpo de prata, peça rica e bem acabada. A cidade e os estudantes lhe fizeram um grave e alegre recebimento: trouxeram as santas relíquias da Sé ao Collégio em procissão solene, com flautas, boa música de vozes e danças. A Sé, que era um estudante ricamente vestido, lhe fez uma fala do contentamento que tivera com sua vinda; a Cidade lhe entregou as chaves; as outras duas virgens, cujas cabeças já cá tinham a receberam à porta de nossa igreja; alguns anjos as acompanharam, porque tudo foi a modo de diálogo. Toda festa causou grande alegria no povo, que concorreu quase todo (Cardim, 1980, 143).

Mais evidente, ainda, a presença de alegorias, modelo do teatro medieval: um estudante representando a Sé, outro, a Cidade, outros dois a Cabeça de Duas Virgens e tudo a modo de diálogo, ou seja, com representação. Há, nessa representação, para acentuar a desobediência legal, a presença de personagens femininas; a Sé, a Cidade, a Cabeça de Duas Virgens, que eram caracterizadas provavelmente por estudantes (segundo Leite, baseando-se na interessante recomendação do padre visitador Manuel de Lima: "nas obras, que se fizerem, não se vistam moços como mulheres, mas como ninfas, alevantando a roupa um palmo do chão"). Nos colégios, era para se evitar tragédias e comédias, e fazer representações apenas para ensinar latim e obras devotas durante as aulas. Deviam evitarse, ainda, personagens femininas, e representar apenas as Santas Virgens (Leite, 2004, 417). Nesse item, Anchieta talvez tenha sido ainda mais desobediente, já que, em uma de suas principais peças de teatro, o auto da Vila de Vitória, a personagem principal contracena com Ingraditão, uma velha prenhe de Lúcifer, Satanás, mas também de Calvino, Lutero...

\section{Pero Dias: pedra e dia}

Segundo Cardoso (Anchieta, 1977, p. 194), a peça "Diálogo de Pero Dias" pode ter sido realizada nos anos de 1575 ou 1592. O ano de 1575 seria um ano após a aprovação de Roma para a festa dos mártires; o ano de 1592, porque Anchieta estaria em Salvador nessa época para participar de uma Congregação da Companhia, que, segundo Leite (2004), teria acontecido em maio. Também em 1592, Anchieta se encontrava em Salvador porque havia sido instalada na cidade a Visitação da Inquisição: "Em 28 de julho de 1591 teve início a Visitação, não sem grande pompa e cerimonial laudatário ao Santo Ofício e à pessoa de Heitor Furtado" (Vainfas, 1995, p. 167). Investigou uma seita indígena, a Santidade Jaguaribe, que fora acolhida na fazenda de Fernão Cabral de Ataíde, um poderoso senhor de engenho da Bahia. Santidade fora destruída cinco anos antes, em 1586, quando Anchieta ainda era o provincial. Há uma carta de Anchieta, de $1^{\circ}$ de dezembro de 1592 , endereçada da Baia, que provaria que ele esteve na cidade nessa época. Para este estudo, supõe-se como data de realização da peça o ano de 1592 porque, também segundo Leite (2004, p. 346, em nota), Beliarte, então Provincial da Companhia no Brasil, em carta de 15 de maio de 1593, escreve sobre o ato da publicação dos editos da Fé, que se realizou na Sé da Bahia, no dia 28 de julho de 1591: "E acabada a missa pregou o Reverendo Padre Marçal Beliarte, Provincial da Companhia de Jesus, a pregação da fé, com muita satisfação, tomando por tema, "tu es Petrus e super hanc petram aedificabo ecclesiam meam". Mesmo tema do "Diálogo de Pero Dias".

Pero Dias, personagem da peça que contracena com Cristo, teve uma morte trágica no mar. O barco onde estava, juntamente com outros padres, irmãos e estudantes da Companhia de Jesus, foi atacado pelo calvinista João Capdeville. Doze missionários 
jesuítas foram trucidados, em 13 ou 14 de setembro de 1571, juntando-se aos outros 40 que haviam sido "martirizados" em 1570, entre eles Inácio de Azevedo, provincial do Brasil que não chegou a assumir seu posto. Em 1574, iniciaram-se as festas desses mártires. José de Anchieta fez essa peça de teatro sobre este mártir, mas não apresentou esse triste acontecimento no mar. Compôs um diálogo em que a alma de Pero Dias contracena com Cristo, transformando, alegoricamente, essas duas personagens etéreas em padre jesuíta e estudante, para ensinar aos "moços" do Colégio como viver a verdadeira vida cristã, segundo a concepção de vida jesuítica do século XVI.

O diálogo foi recomposto por Cardoso com três atos: o primeiro seria uma canção lírica em língua castelhana; o segundo, o diálogo propriamente dito, também em espanhol; o terceiro, uma canção lírica cantada em espanhol. Os três atos são apógrafos e encontramse no "caderno" de Anchieta, isto é, no ARSI sob o códice Opp. NN 24.

Cardoso (Anchieta, 1977, p. 194) assevera ser aceitável que os padres tinham preparado para essa festa uma imagem de Pero Dias para ser carregada pelos estudantes do porto até o adro da Igreja. Então, além dessa suposição e tendo-se como inspiração as descrições de Cardim, relatadas acima, para a festa de Santa Úrsula e as Onze Mil Virgens, tem-se que a imagem do mártir jesuíta seria carregada pelos estudantes do colégio jesuíta de Salvador, do porto até um altar preparado no pátio do Colégio. Os estudantes entoariam cânticos religiosos e seguiriam a procissão junto com os padres, com os moradores da cidade, com os colonos vindos de outras localidades para essa festa religiosa, além de índios das aldeias e aldeamentos em que os jesuítas tinham suas casas. Fogos de artifício, tiros de arcabuz e outras invenções chamariam a atenção dos participantes da festa. Pela cidade, anjos sobrevoariam o porto em frente à igreja. Seriam meninos índios e estudantes do colégio, com suas asas de penas coloridas de aves das matas brasileiras. A imagem de Pero Dias seria depositada no centro do altar portátil, preparado com dosséis e cortinas de tafetá camersim, juntamente com uma cruz de prata dourada de maravilhosa obra. Enquanto isso, os meninos índios cristianizados aproximar-se-iam do altar e tocariam flauta, e os filhos dos colonos e os estudantes do Colégio entoariam cânticos. Dançariam. Todos se preparariam para a representação diante do altar. Cantariam os irmãos e estudantes do Colégio uma cantiga para Pero Dias, composta, é provável, pelo padre Joseph:

Si quieres firmeza y luz

como el Padre Pero Días

Sigue al Salvador Mesías!

Pero Días piedra fue, miembro de la Piedra viva, en que el edificio estriba de toda la santa fe, que los sentidos nos cautiva, No sea tu alma esquiva contra la penosa cruz abrazada de Jesús, piedra mármol y luz viva, Se quieres firmeza y luz. [...]

Como siguió en su vivir

A Jesús su buen amigo, 
Fue de él tan fiel testigo

Que por él vino a morir

En manos del enemigo,

Por amigo tan antiguo,

Trabaja noches y días,

Que te quiere unir consigo,

Y sí lo quieres contigo

Sigue al Salvador Mesías.

(Anchieta, 1977, p. 195)

Pero Dias foi pedra, pois seguiu Cristo, que é pedra, aquela na qual está apoiada a Igreja, tema do edito de instalação do Santo Ofício, que o padre Beliarte escolhera um ano antes ao qual se supõe estar acontecendo essa representação. Nessa cantiga, que pode ter sido cantada em outro momento que não como primeiro ato do Diálogo, estabelecido por Padre Cardoso, aparece em jogo o nome de Pero Dias e nele o tema dessa peça, a firmeza de pedra, Pero, e a iluminação, Dias, que Pero Dias teve em sua fé, morrendo por Cristo. Na terceira estrofe dessa canção está o principal ensinamento de Anchieta para os moços: La fuerza y luz de amor, que teve Pero Dias, nacen de Iesú Mesías, amai-O, entranhas minhas, si queréis luz y vigor, como el Padre Pero Días.

\section{Cristo e Pero Dias dialogando no pátio do Colégio de Jesus}

$\mathrm{O}$ ato II, assim considerado por Cardoso, mas que pode ter sido, também, um diálogo isolado em meio à festa religiosa, traz o mártir jesuíta e Cristo em cena no pátio do Colégio de Jesus. Cristo, essa luz intensa, cuja voz daquele que deve ser o maior poeta de todos os tempos, Dante Alighieri (1998, p. 231), foi vã e incompetente para descrever, da "quinci innanzi Il mio veder fu maggio che Il parlar mostra" (...) é a personagem desse diálogo, falando em espanhol. Estarão, a partir desse momento, divindade e mártir circulando e dialogando no pátio do Colégio para o olhar emocionado e fervoroso dos espectadores.

Cristo pergunta:

Cristo:

Pero, di ¿qué has perdido?

Pero Dias:

Lo que luego hallaré.

Cristo:

¿Perdiste, quizá, la fe?

Pero Dias:

No! Que con todo sentido

por guardaría, trabajé.

Cristo:

¿Quien te dio fuerza e valor, con que la fe no perdiste? 


\section{Pero Dias:}

Tú, Señor, que me quisiste dar tu gracia y fuerte amor, con el cual me previniste.

\section{Cristo:}

¿Como así? ¿Tú no podrías sin eso, creer en mí?

\section{Pero Dias:}

No, Señor, que si creí, fue porque tú me hacías que creyese sólo en ti. Porque, sin ti, ni pensar yo podría cosa buena.

\section{Cristo:}

¿Según o que dices? ¿Es ajena la fe, que te quise dar, de balde, con mano llena?

Pero Dias:

Confieso que Tuya es, pos de esa verdad no huyo, mas yo te pregunto: ¿cuyo es lo que me das, después que haces mío lo tuyo?

Cristo:

Tuyo es; pues te lo doy.

Mas dime: ¿Tú cuyo eres?

Pero Dias:

Pues que todo darme quieres, sin duda que tuyo soy, con todo cuánto me dieres.

\section{Cristo:}

Dices bien, mas dime más:

el Pero, ¿quién te lo dio?

Pero Dias:

Tú poder, que me creó, $\mathrm{y}$, como piedra, me das la fuerza que tengo yo. Porque de mí, nada tengo, si no siempre desmayar. 
Importante e arrojada a presença em cena, no pátio do colégio jesuíta de Salvador na Bahia do século XVI, ou no adro da Igreja, ou ainda, dentro da Igreja, da personagem Cristo, que não representa a si mesmo, o Seu Nascimento, a Sua Paixão, a Sua Ressurreição, como no teatro medieval, mas um padre jesuíta que faz perguntas para seu estudante, no caso o mártir, Pero Dias, que também não representa a si mesmo, sua vida, seu martírio, mas um moço do colégio. Cristo pergunta para Pero o que ele havia perdido; este responde que era algo que logo achará. No entanto, Cristo questiona-o para saber se, por acaso, o que ele havia perdido era a fé. Pero responde que não fora a fé que perdera, pois todo o sentido de sua vida tinha sido por causa de guardar sua fé, porque percebera, ainda em vida, que a verdadeira vida é seguir Cristo. Foi por seguir Cristo, que Pedra é, que lhe deu a força que tem, ensina Pero aos moços e aos espectadores.

Essa maneira de ensinar por meio de perguntas e respostas veio para o Brasil trazida de Portugal. Na carta ânua de maio de 1564, pede padre Antônio Brasques (Leite, 1960, p. 68) ao padre provincial Diogo Miron que "por charidad nos haga mandar la doctrina que allá aguora se ensenã por perguntas y respuestas", pois que das muitas coisas que foram recebidas do reino esta "se mesclo el desabrimento do nos hazer participantes de cosa tan buena e provectosa”. Veja-se, por exemplo, um trecho da Paixão de Cristo composta na forma de perguntas e respostas cantadas na língua mais falada da costa brasileira, atribuída ao Padre Anchieta: "Mestre: Marãpe guá serekóu aé riré? Discípulo: Oipysó ybyrá joasába, áribo, itapygua pupé, ipómojá, pergunta o Mestre: que fizeram depois? Responde o Discípulo: estenderam-no sobre um travessão de lenho e pregaram nele as mãos com pregos de ferro" (1988b, p. 189). Em carta de 1555, diz Anchieta (1988, p. 99), sobre a didática com que se ensinam os meninos nos rudimentos da fé é "responderem umas certas fórmulas que se lhes ensinam, ou mesmo sem ela". Esta fórmula de perguntas e respostas para ensinar a doutrina cristã para rudes e meninos foi aprovada pelo Concílio Tridentino, que a padronizou (Agnolin, 2001). Certamente, Anchieta tenha se inspirado nessa fórmula para facilitar em seu teatro o entendimento dos meninos e dos espectadores rudes e faltos da doutrina, usando um recurso realmente fabuloso, já que quem dialoga no palco não são Mestre e Discípulo, mas a Alma de um mártir, desencarnada, diferente, portanto, da "Alma" do Auto da Alma de Gil Vicente (Bernardes, 2000), que responde, mais comumente, às perguntas feitas por Cristo, a divindade. No final desse jogo de perguntas e respostas, a afirmação dos ensinamentos na voz de Cristo e Pero Dias:

Cristo:

Por eso quise rogar

a mi padre, de quien vengo,

para tu fe no faltar,

que de mí, que piedra soy,

te viene ser "Pero" fuerte.

Pero Dias:

Muy dichosa fue mi suerte,

pues, por tus pisadas, voy

hasta pasar cruda muerte. [...]

(Anchieta, 1977, p. 197). 
O mártir, que mais parece um "minino", conclui com Cristo, semelhante aqui a um padre jesuíta, que é muito ditosa a sorte de quem segue os passos de Cristo (ou seriam os ensinamento do padres, já que Cristo representa alegoricamente os padres jesuítas) até passar crua morte. Nesse diálogo, aparecem claramente os ensinamentos da moral cristã do século XVI, em que é melhor morrer para a vida material, morrer para não morrer, para viver a vida eterna, conforme, por exemplo, Santa Tereza D’Ávila (2001).

Uma fonte de inspiração para pôr Cristo em um palco, no pátio do Colégio, talvez tenham sido Os Exercícios Espirituais, que têm como característica a dramatização, interior, da vida de Cristo (Hernandes, 2008). Na segunda semana, por exemplo, o exercitante, que participa do nascimento de Cristo, deve "ver as pessoas", isto é, ver Nossa Senhora, José, a criada, o menino Jesus depois de nascido, "fazendo-me eu de pobrezinho e criadinho indigno, olhando-os, contemplando-os e servindo-os em suas necessidades, como se me achasse presente com todo acatamento e reverência possíveis" (Loyola, 1966, p. 84). No caso do teatro de Anchieta, no entanto, há uma inversão e não é o "exercitante" que participa como um "pobrezinho e criadinho indigno" da Natividade, mas sim Cristo que participa, como um padre jesuíta, da vida cotidiana de um colégio encravado em meio à mata selvagem do Brasil do século XVI.

No pátio do Colégio de Jesus o diálogo continua:

Cristo:

¿Cómo viste mis pasadas

para por ellas andar?

Pero Dias:

Con tu luz muy singular, con que fueron alumbradas las mías, para acertar, porque el hombre, que camina. enguanto la luz dura, no ofende en la noche obscura.

Cristo:

Por mi caridad divina, has tenido ventura. Por eso te quiso dar el sobrenombre de "Dias".

Pero Dias:

Yo lo creo, sin dudar, que las noches eran mías, en que solía pecar, mas esclareciendo el día que Tu eres, vi me a mi, y sin más tardar, perdí la vida, con alegría, viéndote morir a Ti. 
Cristo:

¿Cómo dices? ¿Que es

perdida

la vida, que no tenias,

cuándo en pecado vivías?

Pero Dias:

Yo teñidla por vida

aunque Tú lo prohibías

Mas esa vida dejé,

que, de verdad, era muerte,

cuando Tú muerte mire

con la luz de gracia y fe,

que me dio Tú mano fuerte.

Cristo:

Esa pérdida te dio

la verdadera ganancia

de la vida, que soy Yo.

Pero Dias:

Señor, toda mi sustancia

de Tú Espíritu nació,

que es la gracia interior;

que los más son accidentes

del mundo, falso e traidor.

Cristo:

Ése da pena y dolor

eternal a sus sirvientes.

Más, cuando al mundo

moriste,

comenzó tu vivir.

Pero Dias:

Sí, que tu vida seguir, es la vida que me diste, para nunca más morir.

Y por ésta no perder, di la vida terrenal...

Cristo:

Con la gracia divinal, que te quise conceder, para hallar la celestial. (Anchieta, 1977, p 198).

Pero Dias encontrou a luz que é Cristo e morreu feliz, imitando o Seu sacrifício. Morrera para a vida material, que é "acidente de um mundo falso e traidor", para poder 
viver a verdadeira e eterna vida na Jerusalém Celeste. Tema central da religiosidade do século XVI, o período de crise da Igreja Católica e não do cristianismo, já que este foi, segundo Febvre (1970, p. 507), "um século inspirado", que procurava acima de todas as coisas um "reflexo divino" e a necessidade em reviver a vida de sacrifícios, martírios, de reviver o cristianismo primitivo, "par le désir de la "restaurer" sur le patron d'une Église primitive dont le mythe séduisait leurs imaginations" (Febvre, 1968, p. 26).

Nos "Exercícios Espirituais", manual de formação espiritual dos jesuítas, obra primeira da pedagogia inaciana, encontra-se essa máxima de que é preciso morrer para si próprio e para o mundo para viver a verdadeira vida, a espiritual. Esta é a moral cristã, porque o mundo terreal é acidente, mundo falso e traidor que dá pena aos seus sirvientes, como ensinaram as personagens Cristo e Pero Dias no adro da Igreja de Salvador, para os moços do Colégio. A moral cristã, dos tempos barrocos de Santa Tereza D’Ávila, Inácio de Loyola e, por que não, José de Anchieta, não pode estar ligada à manutenção da vida como ela é (Bataille, 1988). Ela exige o seu pleno desabrochar no êxtase, cujo arrebatamento leva a uma vida mística, vivendo constantemente com divindades, mártires, santos, no sacrifício da missa, nos "Exercícios Espirituais", nas Igrejas, no teatro, nos encontros poético-dramáticos, com as divindades nas areias das praias, nas praças, igrejas, nos quartos escuros, nos "cubículos" do Colégio de Salvador. Ser cristão (verdadeiro), ensina Loyola (1966), é entregar-se de forma total nas mãos da Vontade Divina, sendo indiferente, totalmente, à realidade material, ao mundo, à carne.

Esse desejo de morte para a salvação da vida, que era tão desejado pelos padres da Companhia de Jesus, pelo menos do século XVI, contrastava com o sentimento dos índios em relação à morte.

Ajuntávanse los negros todos dell'Aldea a ver y admirarse, y yo como los vi juntos dice a una lengua que ahí venía que les dícese alguna cosa de Dios, y ellos todo escuchaban, mas como vino a hablar de la muerte no quisieron oír, y dizian a la lengua que no hablase más, que ya hecho era, que cantasen. Y unos venían con una cosa, otros con otra, scilicet harina y yñames para comeremos, y poniannoslo delante e dizian: Taxemoraíumé, que quiere dizir no me venga mal, porque pensam que le podíanmos dar salud e desta manera vivíamos (Leite, 1954b, p. 44).

Não sabiam os índios e, pelo visto, nem queriam saber, que aquele que sacrificar a vida material, como fez Pero Dias, em vida, e escolher a vida espiritual, teria garantida a ressurreição e a vida eterna, ao lado de Cristo, como diz a poderosa personagem Cristo, aos estudantes e espectadores presentes no Colégio de Jesus. Diz ainda que, imitando o Sacrifício de Cristo, como fez Pero Dias, serão salvos da segunda morte, que é a verdadeira morte, o inferno. Porque o mundo, a carne, a vida não passariam de um melancólico pesadelo, uma ilusão, presa da morte: "Presa de irreprimível decadência, a vida é sonho cujo termo é a morte, limite entre a história e a significação última" (Hansen, 1987, p. 99).

E a "Morte", alegórica, angustiante, circularia pelas matas brasileiras do século XVI, pelo teatro, pelos sermões dos padres, no canto e na dança dos meninos órfãos, mas, literal, tenebrosa e implacável, circulava nos perigos das matas, nas guerras, nos sacrifícios dos rituais antropofágicos, também nas doenças que dizimavam aldeias. " $Y$, por que desto tenga $V$. $R$ más claridade, sepa que uvo entre elhos dos grandes mortandades. La primeira tuvo origem y principio de unas febres", que derrubavam os índios rapidamente e só se podiam socorrer com o espiritual, pois nada se podia fazer com ajuda humana e, assim, com a ajuda de todos, padres, irmãos e estudantes do colégio, "mando el Señor nesta mortandade, por médio de los de la Compañia muchos centanarios de almas al ciel”. 
Causava lágrimas a todos ver e ouvir aqueles índios que tanto bailavam e tanto se regozijavam tristes e calados, alguns sem pai, outros sem seus filhos, mulheres sem seus maridos. Eram tantos e agora, diz Blasques, são tão poucos. A segunda mortandade teria sido ainda pior, "mucho peor que la outra, la qual era unas viruelas o bixigas tan asquerosas y hediondas que no avia quien las pudesse suffrir com la grande hediondez que dellas salia". E, além da ajuda dos Padres e irmãos nas aldeias, era "nuestro Collegio un como Hospital dellos, em donde ganaron mucho nuestro Padres e Hermanos com ellos" (Leite, 1960, p. 54). A Morte trágica, real, que ceifava a vida daqueles índios, trazida pelos europeus, era a esperança de salvação eterna, segundo Cristo, Pero Dias, padre e moço do Colégio de Jesus - mas só para os cristãos que fossem, na fé, iluminados como o dia e fortes como pedra.

Há, então, nessa peça de Anchieta, como nos "Exercícios Espirituais", uma dupla pedagogia, aquela despertada pelos efeitos da plástica teatral, a personagem Cristo, a atmosfera, a alma do mártir em cena, esse ponto a queimar o espírito dos espectadores, levando-os a uma experiência interior provocada por algo que não está presente (propositalmente), o martírio de Pero Dias. E a outra pedagogia, obviamente, os ensinamentos literais da poderosa voz das personagens em cena, voz que faz "passar" as lições, queridas por Anchieta, Loyola, a Igreja Católica, de modo fácil, na fórmula de perguntas e respostas:

Cristo:

Ya me tienes respondido

a lo que te pregunté,

mas no digas "hallaré

lo que tenía perdido".

Antes di: "Ya lo hallé".

Porque por la mala vida

que tú perdiste por mí,

vida de gracia te di,

y tu alma esclarecida

tiene vida eterna en sí.

Pero Dias:

¿Y la vida, que perdió

mi cuerpo, con fiera

espada?

Cristo:

Haz cuenta que ya es

hallada

Y que ya resucitó,

pues será resucitada.

Pero Dias:

Pues digo que ya hallé

lo que perdido tenía.

Cristo:

Por eso te llamaré 
clara luz y fuerte fe, fuerte Pero y claro Día.

(Anchieta, 1977, p. 199)

A pergunta feita por Pero para a divindade é se ele que abandonou a vida (real), iluminado pela Luz que é Cristo, vida que era pecado, na verdade morte, irá ressuscitar. Cristo responde, então, no final do diálogo, a essa pergunta, dizendo que ele não deveria mais dizer que irá ressuscitar, posto que já ressuscitou, pois Pero havia morrido não somente na vida material para não morrer na espiritual (como deveriam fazer todos os cristãos), mas teve a sorte de ser martirizado (morto mesmo) pelo calvinista Capdeville. Tornou-se testemunha do sacrifício de Cristo e, como tal, pedra e luz, firmeza e iluminação, exemplo para a vida dos moços e espectadores que ali estão.

\section{Ato Final}

Finda a representação, Cristo, o padre jesuíta com uma coroa de espinhos, seguido pela alma de Pero Dias, um dos estudantes do colégio, com suas asas representando a alma do mártir jesuíta, seguiriam em procissão para o interior da Igreja do Colégio ou atravessariam a cidade indo para a Sé. Um padre viria logo atrás da divindade e do mártir e carregaria a imagem de Pero Dias para seu lugar de origem, um dos altares internos da igreja. Os meninos índios tocariam suas flautas, os estudantes cantariam, dançariam, para surpresa do homem do Santo Ofício, não acostumado a músicas e cantos nas celebrações dos jesuítas em Roma. No altar da igreja, os estudantes recitariam, em coro, um poema elaborado para a festa dos mártires pelo padre Joseph:

Los que muertos, veneramos

Por suo Dios,

Si no los seguimos nos,

¿qué ganamos?

Los que las honras del mundo

despreciaron,

y las deshonras amaron

de la cruz,

éstos, con su buen Jesús, de la muerte triunfaron.

Sin ningún temor pasaron

A la vida, que esperamos,

En sus manos con los ramos

Del triunfo, que alcanzaron,

Los que muertos veneramos.

$[\ldots]$

Dejamos el mundo malo, que cautivos nos tenía.

Venimos, con alegría,

a llevar el santo palo

de la cruz, de noche y día. 


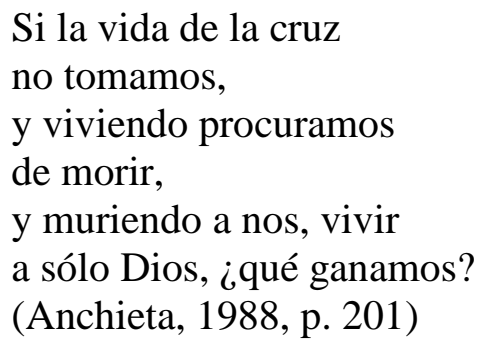

Para evangelizar ou então formar quadros para a Companhia de Jesus no Brasil havia inúmeros problemas. Os índios ou mamelucos cristianizados foram proibidos de ingressar na ordem, pois eram "rudes" e permaneciam apenas nos rudimentos da fé. Os cristãos que aqui estavam antes da chegada dos jesuítas, no século XVI, ingressaram na ordem como coadjutores, mas não se tornavam sacerdotes. Poucos eram os filhos dos principais que queriam ir para o Colégio, e, quando iam, tinham dificuldades de se adaptar às regras da Companhia. Segundo Anchieta: "Os estudantes nesta terra, além de serem poucos, também sabem pouco, por falta dos engenhos e não estudarem com cuidado, nem a terra o dá de si por ser relaxada, remissa e melancólica, e tudo se leva em festas, cantar e folgar" (Anchieta, 1988, p. 423 ss). Anchieta contabiliza, em 1584, não mais de 35 estudantes da Companhia de Jesus nos colégios espalhados pelo Brasil, enquanto estudantes externos, que só queriam aprender a ler, escrever e contar, apenas no Colégio de Jesus seriam 70. Ou seja, o Colégio de Jesus era uma instituição que formava mais gente para trabalhar no "comércio" do que de obreiros para o serviço divino. Era preciso, então, recorrer a estudantes vindos de fora. Podiam ser até aqueles meninos de pouca idade que não eram aceitos, por esse motivo, na Companhia de Jesus, na Europa, pois aqui eles seriam úteis e não teriam problemas com alimentação, diz o Padre Azevedo, Visitador, em 1568 (Leite, 1960). Por fim, quando esses estudantes vindos de além-mar chegavam aqui aqueles que não eram mortos no mar, como aconteceu em 1570 e 1571, com mais de 40 deles, os mártires -, encontravam um ambiente totalmente diferente daquele da Europa. Mata fechada, peregrinações por aldeias, igrejas e casas de taipa e barro, se não de palmas, animais peçonhentos, mulheres índias nuas que "corriam trás dos moços", índios antropófagos. Nos caminhos que tinham que fazer pela floresta, circulavam os espíritos malfazejos das matas, os añangá, os macaxera, os curupiras, além, é claro, de animais ferozes de carne e osso, como os jaguares. No mar, os naufrágios. Nas cidades, os moços conviviam em meio a homens degredados que vinham para esse lugar como castigo; alguns, para saldar suas penas, trabalhavam para os jesuítas no Colégio. Sobre tal situação, escreve Anchieta (1988, p. 74), em carta aos irmãos enfermos de Coimbra, de 1554:

Também vos digo que não basta com qualquer fervor sair de Coimbra, senão que é necessário trazer alforje cheio de virtudes adquiridas, porque de verdade os trabalhos que a Companhia tem nesta terra são grandes e acontece andar um irmão entre os índios seis, sete meses no meio da maldade e seus ministros e sem ter outro com quem conversar senão com eles; donde convém ser santo para ser irmão da Companhia. Não vos digo mais, senão que aparelheis grande fortaleza interior e grandes desejos de padecer, de maneira que os trabalhos sejam muitos, vos pareçam pouco. Fazei um grande coração, porque não tereis lugar para estar meditando em vossos recolhimentos, senão in medio iniquitatis et super flumina Babylonis e sem dúvida porque em Babilônia rogo vos omnes ut sempre ore tis pro paupere frate Joseph. 
Era preciso ser iluminado e pedra, como Pero Dias foi, segundo Anchieta, para vir ao Brasil no século XVI, para transformar esse lugar em católico e cristão, em que não havia tempo para meditação nem lugar para recolhimento e que se vivia seis, sete meses metido entre os índios, ou seja, vivendo em uma cultura tão diferente daquela das cidades europeias, do colégio jesuíta de Coimbra, onde estão recolhidos os irmãos enfermos à quem Anchieta endereça essa recomendação. No Colégio de Jesus, não havia tempo para aprender profundamente os ensinamentos cristãos; era preciso ir à prática, entrar logo para o serviço divino, a fim de salvar almas, livrando-as da vida temporal para conduzi-las à vida espiritual, eterna.

\section{Referências:}

AGNOLIN, A. Jesuítas e selvagens: o encontro catequético no século XVI. Revista de História, v. 144, 2001. Disponível em: 〈http://www.scielo.br〉. Acesso em: nov. 2011.

ANCHIETA, J. Cartas: informações, fragmentos históricos e sermões. Belo Horizonte: Itatiaia; São Paulo: Editora da Universidade de São Paulo, 1988.

ANCHIETA, J. Teatro de Anchieta: obras completas; originais acompanhados de tradução versificada, introdução e notas Pe. Armando Cardoso. São Paulo: Loyola, 1977.

BATAILlE, G. O Erotismo. Tradução de João Bernard da Costa. 3. ed. Lisboa: Edições Antígona, 1988.

BERnARDES, J. A. C. Actas do Congresso Internacional, Anchieta em Coimbra (1548-1998). Porto: Edição da Fundação Eng. Antonio de Almeida Porto, 2000.

BITTAR, M. O estado da arte em história da educação brasileira após 1985: um campo em disputa. In: LOMBARDI, J. C.; SAVIANI, D.; NASCIMENTO, M. I. M. (Orgs.). Navegando pela história da educação. Campinas: HISTEDBR, 2006.

BITTAR, M; FERREIRA, A. A pesquisa em história da educação colonial. In: PAIVA, J. M.; BITTAR, M.; ASSUNÇÃO, P. (Orgs.). Educação, história e cultura no Brasil colonial. São Paulo: Arké, 2007.

BITTAR, M; FERREIRA, A. História, epistemologia marxista e pesquisa educacional brasileira. Educação e Sociedade, v. 30, n. 107, p. 489-511, 2009.

CARDIM, F. Tratados da terra e gente do Brasil. Introdução de Rodolfo Garcia. Belo Horizonte: Itatiaia; São Paulo: Editora da Universidade de São Paulo, 1980.

CAXA, Quirício e RODRIGUES, Pero. Primeiras Biografias de José de Anchieta; introduções e notas do Pe. Helio Abranches Viotti, S.J., São Paulo: Edições Loyola, 1988.

CONSTITUIÇÕES da Companhia de Jesus e normas complementares. São Paulo: Edições Loyola, 1997.

DANTE. A Divina Comédia: Paraíso. Tradução e notas de Italo Eugênio Matos. São Paulo: Ed. 34, 1998

FEBVRE, L. Au coeur religieux du XVI siècle. 2. ed. Paris: Bibliothèque Générale de L'École Pratique des Hautes Études, 1968.

FEBVRE, L. O problema da descrença no século XVI: a religião de Rabelais. Tradução de Rui Nunes. Lisboa: Editorial Início, 1970. 
FERREIRA JÚNIOR, A.; BITTAR, M. Pluralidade lingüística, escola de bê-a-bá e teatro jesuítico no Brasil do século XVI. Educação e Sociedade, v. 25, n. 86, p. 472-482, 2004. FOUCAULT, M. Estética, literatura e pintura, música e cinema. Tradução de Inês Autran Dourado Barbosa. 2. ed. Rio de Janeiro: Forense Universitária, 2009.

HANSEN, J. A. Alegoria: construção e interpretação da metáfora. 2. ed. São Paulo: Atual, 1987.

HERNANDES, P. R. Meraviglia o teatro de José de Anchieta. 2006. Tese (Doutorado) Universidade Estadual de Campinas, Campinas.

HERNANDES, P. R. Os exercícios espirituais e o teatro. In: PAIVA, J. M.; BITTAR, M.; ASSUNÇÃO, P. (Orgs.). Educação, história e cultura no Brasil colonial. São Paulo: Arké, 2007.

HERNANDES, P. R. Os Exercícios Espirituais e a Companhia de Jesus. Revista do HISTEDBR Online, n. 30, 2008. Disponível em: <http://www.histedbr.fae.unicamp.br/revista/edicoes30/art18_30.pdf $>$. Acesso em: nov. 2011.

LEITE, S. S. J. Cartas dos primeiros jesuítas do Brasil - 1538-1553. São Paulo: Comissão do IV centenário da cidade de São Paulo, 1954a. v. 1.

LEITE, S. S. J. Cartas dos primeiros jesuítas do Brasil - 1553-1558. São Paulo: Comissão do IV centenário da cidade de São Paulo, 1954b. v. 2.

LEITE, S. S. J. História da Companhia de Jesus no Brasil. Organização de César Augusto dos Santos et al. São Paulo: Edições Loyola, 2004. v. 1.

LEITE, S. S. J. Monumenta Brasiliae - 1563-1568. Coimbra: Tipografia da Atlântica, 1960.

LOYOLA, I. Exercícios Espirituais. Orientação de tradução e anotações de Padre Géza Kövecses S. J. 3. ed. Porto Alegre, 1966.

NÓBREGA, M. Cartas Jesuíticas 1. Belo Horizonte: Itatiaia; São Paulo: Editora Universidade de São Paulo, 1988.

SANTA TEREZA D'AVILA. Escritos de Tereza de Ávila. Tradução de Adail Ubirajara Sobral, Maria Stela Gonçalves, Marcos Marcionilo, Madre Maria José de Jesus. São Paulo: Edições Loyola, 2001.

VAINFAS, R. A heresia dos índios: catolicismo e rebeldia no Brasil colonial. São Paulo: Companhia da Letras, 1995.

VEYNE, P. M. Como se escreve a história: Foucault revoluciona a história. Tradução de Alda Baltar e Maria Auxiliadora Kneepp. 4. ed. Brasília: Editora Universidade de Brasília, 2008.

Notas:

${ }^{1}$ O fato de o próprio Anchieta tratar-se como "um irmão" não é de se estranhar, pois assim ele se aponta em outra parte desse mesmo fragmento histórico em que está narrando a vida do padre Manuel da Nóbrega: "Quando deixou o irmão companheiro entre os Tamoios indo-se para São Vicente [...]", sabendo que este irmão passava perigo de vida, "teve tanto sentimento e lágrimas que fez um grande pranto cheio de devoção deante de Nosso Senhor e dos irmãos, arremessado sobre um leito, dizendo entre outras coisas: Ah! Meu 
Irmão, que vos deixei só entre inimigos [...]”. Segundo Anchieta, ainda nesse relato, Deus enviou alguns principais para S. Vicente e assegurou a vida do irmão. Mesmo assim, Nóbrega "lhe escreveu uma carta sobre isso, cujo princípio era: 'Irmão, se ainda estais vivo'” (Anchieta, 1988, p. 483). Nesse caso, não há dúvida de que o irmão em causa é José de Anchieta, companheiro de Nóbrega, que ficou refém em Iperoig e tratando da paz com os Tamoios.

${ }^{2}$ Há muitas controvérsias sobre a autoria de Anchieta nas peças de teatro. Serafim Leite, um jesuíta do início do século XX (2004), chega a pôr em dúvida a autoria de peças atribuídas a ele e que são autógrafas: o jesuíta canarino poderia ter copiado aquelas peças para representá-las nos lugares em que ele estivesse. Armando Cardoso (Anchieta, 1977), um jesuíta do final do mesmo século, assegura que até as peças que são apógrafos são seguramente do jesuíta, já que se teriam várias provas de que copistas teriam escrito aquelas peças e espalhado pelos lugares em que estavam os jesuítas. Neste estudo, "não importa quem fala", como diz Beckett, parafraseado por Foucault (2009), pois o que importa é o que foi dito e para quem.

Recebido em

janeiro/2012

Aprovado em julho/2012 